\title{
The efficacy of sweet orange (Citrus sinensis (I). osbeck) peels in the preservation of plain cake at ambient temperature
}

\begin{abstract}
The efficacy of sweet orange (Citrus sinensis) peels in the preservation of plain cake at ambient temperature was evaluated. $C$. sinensis peels were collected from orange sellers in Angwan Rukuba market, Jos North, Nigeria and prepared into aqueous and $\mathrm{n}-\mathrm{Hexane}$ extracts as to determine its phytochemicals and $\mathrm{pH}$. Samples of cake (A and B) were prepared, Sample A was treated with $5 \mathrm{~g}, 3 \mathrm{~g}$, and $1 \mathrm{~g}$ respectively of $C$. sinensis peels crude powder and sample B (control) was treated with $10 \mathrm{ml}$ of brandy $(40 \%$ alcohol). The samples were kept at ambient temperature. The sensory attributes of the cake samples were evaluated for texture, taste and flavour using five persons for three months. The phytochemical tests of the extract and the crude powder, showed the presence of flavonoids, Tannins, Saponin, Alkaloids, Sterols and Glycosides. The $\mathrm{pH}$ of the crude powder and extracts were 5.6 and 5.7. respectively. Result of Analysis of Variance revealed that, while there was no significant differences $(p>0.05)$ observed in both bacterial and fungal loads of samples treated at various concentrations of the C. sinensis for the first one month, there was a significant difference $(p<0.05)$ in the microbial loads of the samples at the second and third months of storage respectively. For the sensory evaluation, samples treated with C.sinensis peels were significantly preferred $(\mathrm{p}<0.05)$ than the control for the period of three months. Thus, the results obtained indicates that $C$. sinensis peels, which is a waste, have preservative properties and may be applied to plain cakes, if all the standard baking conditions are observed.
\end{abstract}

Volume 8 Issue 2 - 2018

\author{
lbejekwe AN, Nyam MA \\ Department of Plant Science and Technology, University of Jos, \\ Nigeria
}

Correspondence: Ibejekwe Adaeze Ngozi, Department of Plant Science \& Technology, University of Jos, Nigeria, Tel 08065507466, Email adazengozi@gmail.com

Received: November 30, 2017| Published: March 30, 2018

Keywords: sweet orange, peels, preservation, plain cake

\section{Introduction}

Bakery products are valuable source of nutrients in our diet providing us with calories and protein requirement. Cake is a good example of bakery products made from cereals. ${ }^{1}$ Cake is a cherished food source for people throughout the whole world. Cakes are baked with, flour, sugar, fat, eggs, preservatives and its composition makes it rich food source. Cakes are used for special occasions such as wedding, birthdays, parties and special events. Despite these aesthetic properties of cakes, they are still subjected to spoilage problems; these include physical, chemical and microbiological spoilage. Properly handled cakes generally lack sufficient amounts of moisture to slow growth of any microorganism, except moulds. As normal cooking temperature destroy most fungal spores. ${ }^{1}$

The growth of bacteria on cake is restricted by low water activity and low $\mathrm{pH}$. Bacterial spoilage in cake causes ropiness. Ropiness which can develop very rapidly under warm and humid conditions. Ropiness is caused mainly by Bacillus subtilis but other species of Bacillus are capable of causing rope and these include Bacillus licheniformis, Bacillus megaterium and Bacillus cereus. ${ }^{1,2}$ Seiler et al., ${ }^{3}$ also noted that of the 323 outbreaks of food poisoning which occurred in Britain between 1969 and 1972, cakes and desserts contributed 3 percent of the Staphylococcus aureus food poisoning.

A large amount of by-products are formed as waste during the production of orange juice. ${ }^{4}$ that is to say that, Orange peels pollute the environment to great extent and this environmental pollution can be reduced if orange peels are put into proper use. Orange peels are rich in nutrients, which can be used as drugs and as food supplements. ${ }^{5}$ A study carried out by Narjis et al. ${ }^{6}$ reveals that antimicrobial activity of orange peels was active against microorganisms such as; Acromonas hydrophila, Klebsiella pneumonia, Pseudomonas aeruginosa, Esherichia coli, Pseudomonas fluorescenes, Proteus spp, Staphylococcus aureus and Listeria spp.

\section{Material and methods}

\section{Collection of plant samples}

$2 \mathrm{~kg}$ of fresh orange peels were collected from Angwan Rukuba junction in Jos North Local Government Area of Plateau state. Plant Sample was identified and authenticated by the department of Plant Science and Technology, University of Jos.

The sample was washed with $5 \% \mathrm{NaCl}$ and rinsed with tap water; the $\mathrm{pH}$ of the crude powder was measured using a $\mathrm{pH}$ meter.

\section{Phytochemical screening}

The aqueous, n-hexane extracts and crude powder of the peels were screened to determine the bioactive ingredients. Using standard procedure adopted from Tease \& Evans. ${ }^{7}$ 


\section{Test for alkaloids (wagner's test)}

Five percent $(5 \%)$ sulphuric acid and one milliliter $(1 \mathrm{ml})$ of wagner's reagent was added drop by drop. A reddish-brown precipitate indicated the presence of alkaloids.

\section{Test for tannins (ferric chloride) test}

Five milliliters $(5.0 \mathrm{mls})$ of distilled water was added to two milliliters $(2.0 \mathrm{ml})$ of the extract and three (3) drops of ferric chloride was added to the extract. The mixture was observed for a blue or greenish-black colour which indicated the presence of tannins.

\section{Test for sterols and triterpenes}

Two millilitres $(2.0 \mathrm{mls})$ of the extracts was mixed with one millilitres $(1.0 \mathrm{ml})$ of acetic anhydride and one milliliters $(1 \mathrm{ml})$ of concentrated sulphuric acid was carefully added, down the side of the test tube. The appearance of a brownish-red colour indicated the presence of sterols and triterpenes.

\section{Test for saponins (general test)}

Five milliliters $(5.0 \mathrm{mls})$ of distilled water was added to two millilitres $(2.0 \mathrm{mls})$ of the plant extract was shaken vigorously for two (2) minutes. The formation of an emulsion indicated the presence of saponins.

\section{Test for flavonoids (sodium hydroxide test)}

Five milliliter $(5.0 \mathrm{ml})$ of $20 \%$ sodium hydroxide was added to five milliliters $(5.0 \mathrm{ml})$ of the extract. A yellow solution indicated the presence of flavonoids.

\section{Test for phenols}

Two milliliters $(2.0 \mathrm{mls})$ of ferric chloride was added to two millilitres $(2.0 \mathrm{mls})$ of extract in test tubes. A deep bluish-green solution indicated the presence of phenol.

\section{Test for cardiac glycosides (lieberman's test)}

Two milliliters $(2.0 \mathrm{ml})$ of the plant extract was dissolved in two millilitres $(2.0 \mathrm{ml})$ of acetic anhydride and cooled in water bath Sulphuric acid was added along side of the test tube. A colour change from violet to blue then to green indicated the presence of the cardiac glycoside.

\section{Test for carbohydrates (benedicts test)}

Two milliliters (2.0mls) of benedicts reagent was added to five (5) drops of extract and boil on a hot plate for five (5) minutes. Formation of brick red precipitate indicated a positive test.

\section{Microbiological analysis of the cake baked using orange peels as preservative}

Cake was prepared using crude powder of orange peel as preservative in the different treatment of $5 \mathrm{~g}, 3 \mathrm{~g}$, and $1 \mathrm{~g}$ respectively in three replications. Another cake was prepared with $10 \mathrm{ml}$ of $40 \%$ alcohol (Brandy) preservatives as control www.nigerianfoodtv.com/ nigerian.cakerecipe.modified. ${ }^{8}$ A portion of the baked cake containing orange peels preservatives and its control sample was kept at ambient temperature and cultured every one month using pour plate method for bacteria and surface growing for fungi to determine the presence or absence of spoilage microorganisms in the cake for three months.

\section{Sensory test of the treated and control cake samples}

There was sensory test at one month interval for three months using five persons. Where the following parameters were evaluated; flavor, taste, texture and acceptability.

\section{Result}

\section{The results of phytochemical screening of extracts (aqueous and $\mathbf{n}-$ hexane) and the crude powder}

The results obtained in the phytochemical, indicates the presence of important bioactive chemicals constituents found in peels; flavonoids, alkaloids, tannins and phenolic compounds were more present in the extracts and the crude powder where flavonoids was highly present in aqueous extract than others, as indicated in Table 1.

Table I Phytochemical screening of the sweet orange peels extracts (aqueous and $\mathrm{n}$ hexane) and crude powder

\begin{tabular}{ll}
\hline Chemical constituents & Crude powder \\
\hline Alkaloids & ++ \\
Saponin & + \\
Tannins & ++ \\
Flavonoids & ++ \\
Carbohydrates & ++ \\
Sterols & + \\
Triterpenoids & - \\
Anthruquinones & - \\
Phenolic & ++ \\
Cardiac glycosides & + \\
Glycosides & ++
\end{tabular}

Key: -,Absent; +, Present; ++, moderately present; +++, Highly present

\section{$\mathrm{pH}$ value}

The $\mathrm{pH}$ of the C.sinensis peels, crude powder and extracts was found to be 5.6 and 5.7 respectively. As shown in Table 2 .

Table $2 \mathrm{pH}$ value of the sweet orange peels crude powder and extracts

\begin{tabular}{llll}
\hline Samples & \multicolumn{3}{l}{$\mathbf{p H}$ values } \\
\hline & $\mathrm{I}$ & 2 & 3 \\
\cline { 2 - 4 } Aqueous extract & 5.7 & 5.7 & 5.7 \\
n-Hexane extract & 5.6 & 5.7 & 5.6 \\
Crude powder & 5.6 & 5.6 & 5.6 \\
\hline
\end{tabular}

Key: I, First Test; 2, second test; 3, Third Test

Monthly bacteria evaluation of preservative efficacy of sweet orange peels and a conventional preservative (brandy) as control in storing plain cake within three months

The result of the study reveals significant difference in the preservative level of the three $[5 \mathrm{~g}, 3 \mathrm{~g}, 1 \mathrm{~g}]$ treatments with control at $(\mathrm{p}>0.05)$, in 24-48 hours of Month 1. In Month 2, significant difference 
in effect was observed between the four treatments. The highest occurrence was observed in the control treatment with (3.03 \pm 0.5$)$, $(2.12 \pm 0.8)$ and $(1.24 \pm 0.5)$ respectively that is, least effect, while the least occurrence was similar in the three treatments that is high effect of the preservative. In Month 3, significant difference effect was

Table 3 Monthly bacteria evaluation of preservative efficacy of sweet orange peel and a conventional (brandy) preservative as control in storing plain cake within three months observed within the three treatments. In 24 hours, similar trend was observed where all CFUs had the least preservative effect on Control $10^{1}(4.33 \pm 0.07), 10^{2}(3.89 \pm 0.52), 10^{3}(3.71 \pm 0.0 .45), 10^{4}(3.31 \pm 0.46)$, $10^{5}(2.77 \pm 0.5)$ and $10^{6}(2.77 \pm 0.55)$, while the highest was similar on $\mathrm{T}_{1}, \mathrm{~T}_{2}$, and $\mathrm{T}_{3}$ in all CFUs. As shown in Table 3 .

\begin{tabular}{|c|c|c|c|c|c|c|c|c|c|c|c|c|}
\hline \multirow[b]{3}{*}{ CFU } & \multicolumn{12}{|l|}{ Month I } \\
\hline & \multicolumn{6}{|l|}{24 hours } & \multicolumn{6}{|l|}{48 hours } \\
\hline & $10^{1}$ & $10^{2}$ & $10^{3}$ & $10^{4}$ & $10^{5}$ & $10^{6}$ & $10^{1}$ & $10^{2}$ & $10^{3}$ & $10^{4}$ & $10^{5}$ & $10^{6}$ \\
\hline TI & $0.7 I \pm 0.0$ & $0.71 \pm 0.0$ & $0.7 \mid \pm 0.0$ & $0.71 \pm 0.0$ & $0.7 I \pm 0.0$ & $0.71 \pm 0.0$ & $0.7 \mid \pm 0.0$ & $0.7 I \pm 0.0$ & $0.7 I \pm 0.0$ & $0.7 I \pm 0.0$ & $0.7 \mid \pm 0.0$ & $0.7 I \pm 0.0$ \\
\hline $\mathrm{T} 2$ & $0.7 I \pm 0.0$ & $0.71 \pm 0.0$ & $0.7 I \pm 0.0$ & $0.7 I \pm 0.0$ & $0.7 I \pm 0.0$ & $0.7 I \pm 0.0$ & $0.71 \pm 0.0$ & $0.7 I \pm 0.0$ & $0.7 I \pm 0.0$ & $0.71 \pm 0.0$ & $0.7 I \pm 0.0$ & $0.7 I \pm 0.0$ \\
\hline T3 & $0.7 \mid \pm 0.0$ & $0.7 I \pm 0.0$ & $0.7 \mid \pm 0.0$ & $0.7 \mid \pm 0.0$ & $0.7 \mid \pm 0.0$ & $0.7 I \pm 0.0$ & $0.7 \mid \pm 0.0$ & $0.7 \mid \pm 0.0$ & $0.7 I \pm 0.0$ & $0.7 \mid \pm 0.0$ & $0.7 \mid \pm 0.0$ & $0.7 I \pm 0.0$ \\
\hline \multirow[t]{2}{*}{ C } & $1.5 I \pm 0.6$ & $0.97 \pm 0.4$ & $0.7 I \pm 0.0$ & $0.71 \pm 0.0$ & $0.7 I \pm 0.0$ & $0.71 \pm 0.0$ & $1.71 \pm 0.05$ & $0.97 \pm 0.45$ & $0.97 \pm 0.46$ & $0.7 I \pm 0.0$ & $0.7 I \pm 0.0$ & $0.71 \pm 0.0$ \\
\hline & \multicolumn{12}{|l|}{ Month 2} \\
\hline CFU & $10^{1}$ & $10^{2}$ & $10^{3}$ & $10^{4}$ & $10^{5}$ & $10^{6}$ & $10^{1}$ & $10^{2}$ & $10^{3}$ & $10^{4}$ & $10^{5}$ & $10^{6}$ \\
\hline TI & $1.11 \pm 0.0^{\mathrm{a}}$ & $0.71 \pm 0.0^{\mathrm{a}}$ & $0.7 \mathrm{I} \pm 0.0^{\mathrm{a}}$ & $0.7 I \pm 0.0$ & $0.71 \pm 0.0^{\mathrm{a}}$ & $0.7 I \pm 0.0$ & $0.71 \pm 0.0^{a}$ & $0.7 I \pm 0.0^{a}$ & $0.7 \mathrm{I} \pm 0.0^{\mathrm{a}}$ & $0.7 \mathrm{I} \pm 0.0^{\mathrm{a}}$ & $0.7 \mathrm{I} \pm 0.0^{\mathrm{a}}$ & $0.7 I \pm 0.0$ \\
\hline T2 & $0.7 I \pm 0.0^{a}$ & $0.7 \mathrm{I} \pm 0.0^{\mathrm{a}}$ & $0.7 I \pm 0.0$ & $0.7 I \pm 0.0$ & $0.7 I \pm 0.0^{\mathrm{a}}$ & $0.7 I \pm 0.0$ & $0.7 \mathrm{I} \pm 0.0^{\mathrm{a}}$ & $0.7 \mathrm{I} \pm 0.0^{\mathrm{a}}$ & $0.7 \mathrm{I} \pm 0.0^{\mathrm{a}}$ & $0.7 \mathrm{I} \pm 0.0^{\mathrm{a}}$ & $0.7 I \pm 0.0$ & $0.7 I \pm 0.0$ \\
\hline T3 & $0.7 I \pm 0.0^{a}$ & $0.7 \mathrm{I} \pm 0.0^{\mathrm{a}}$ & $0.7 I \pm 0.0$ & $0.7 I \pm 0.0$ & $0.7 I \pm 0.0$ & $0.7 \mathrm{I} \pm 0.0^{\mathrm{a}}$ & $0.7 I \pm 0.0^{a}$ & $0.7 I \pm 0.0^{a}$ & $0.7 \mathrm{I} \pm 0.0^{\mathrm{a}}$ & $0.7 I \pm 0.0^{a}$ & $0.7 I \pm 0.0$ & $0.7 I \pm 0.0$ \\
\hline \multirow[t]{3}{*}{ C } & $3.03 \pm 0.5^{b}$ & $2.12 \pm 0.8^{b}$ & $1.50 \pm 0.0$ & $1.50 \pm 0.0$ & $1.24 \pm 0.5^{b}$ & $1.50 \pm 0.0$ & $3.45 \pm 0.64^{b}$ & $2.64 \pm 0.37^{b}$ & $2.08 \pm 0.5 \mathrm{I}^{\mathrm{b}}$ & $1.74 \pm 0.42^{\mathrm{b}}$ & $1.50 \pm 0.0$ & $1.24 \pm 0.45$ \\
\hline & NS & NS & NS & NS & NS & NS & NS & NS & NS & NS & NS & NS \\
\hline & \multicolumn{12}{|l|}{ Month 3} \\
\hline CFU & $10^{1}$ & $10^{2}$ & $10^{3}$ & $10^{4}$ & $10^{5}$ & $10^{6}$ & $10^{1}$ & $10^{2}$ & $10^{3}$ & $10^{4}$ & $10^{5}$ & $10^{6}$ \\
\hline TI & $0.7 I \pm 0.0^{\mathrm{a}}$ & $0.7 I \pm 0.0^{a}$ & $0.7 \mathrm{I} \pm 0.0^{\mathrm{a}}$ & $0.7 I \pm 0.0^{\mathrm{a}}$ & $0.71 \pm 0.0^{\mathrm{a}}$ & $0.7 I \pm 0.0^{\mathrm{a}}$ & $0.71 \pm 0.0^{\mathrm{a}}$ & $0.7 I \pm 0.0^{\mathrm{a}}$ & $0.7 I \pm 0.0^{a}$ & $0.7 I \pm 0.0^{\mathrm{a}}$ & $0.7 \mathrm{I} \pm 0.0^{\mathrm{a}}$ & $0.7 \mathrm{I} \pm 0.0^{\mathrm{a}}$ \\
\hline $\mathrm{T} 2$ & $1.29 \pm 1.01^{\mathrm{a}}$ & $1.29 \pm 0.0^{\mathrm{a}}$ & $1.11 \pm 1.0^{\mathrm{a}}$ & $1.22 \pm 0.0^{\mathrm{a}}$ & $0.71 \pm 0.0^{\mathrm{a}}$ & $0.7 I \pm 0.0^{\mathrm{a}}$ & $0.69 \pm 1.70^{\mathrm{a}}$ & $1.69 \pm 1.70^{\mathrm{a}}$ & $1.31 \pm 1.03^{\mathrm{a}}$ & $1.31 \pm 0.0^{\mathrm{a}}$ & $0.7 \mathrm{I} \pm 0.0^{\mathrm{a}}$ & $1.11 \pm 0.69^{a}$ \\
\hline T3 & $0.7 I \pm 0.0^{\mathrm{a}}$ & $0.7 I \pm 0.0^{a}$ & $0.7 \mathrm{I} \pm 0.0^{\mathrm{a}}$ & $0.7 I \pm 0.0^{\mathrm{a}}$ & $0.7 I \pm 0.0^{\mathrm{a}}$ & $0.7 \mathrm{I} \pm 0.0^{\mathrm{a}}$ & $0.7 I \pm 0.0^{\mathrm{a}}$ & $0.7 I \pm 0.0^{\mathrm{a}}$ & $0.7 I \pm 0.0^{\mathrm{a}}$ & $0.7 I \pm 0.0^{\mathrm{a}}$ & $0.7 I \pm 0.0^{\mathrm{a}}$ & $0.7 \mathrm{I} \pm 0.0^{\mathrm{a}}$ \\
\hline C & $4.33 \pm 0.07^{b}$ & $3.89 \pm 0.52^{\mathrm{b}}$ & $3.7 I \pm 0.0 .45^{b}$ & $3.31 \pm 0.46^{b}$ & $2.77 \pm 0.5^{b}$ & $2.77 \pm 0.55^{b}$ & $5.93 \pm 0.64^{b}$ & $5.5 \mathrm{I} \pm 1.07^{\mathrm{b}}$ & $4.90 \pm 0.5 \mathrm{I}^{\mathrm{b}}$ & $4.33 \pm 0.65^{b}$ & $3.55 \pm 0.19^{b}$ & $3.01 \pm 0.23^{b}$ \\
\hline
\end{tabular}

Monthly fungi evaluation of preservative efficacy of sweet orange peels, and a conventional preservative (brandy), as control in storing plain cake within three months

No significant difference was observed in the preservative level of the three $[5 \mathrm{~g}, 3 \mathrm{~g}, 1 \mathrm{~g}]$ treatments with control at $(\mathrm{p}>0.05)$, in $24-48$ hours of Month 1. At the end of month 2 and 3, significant difference in effect was observed between the three treatments respectively.

Table 4 Monthly fungi evaluation of preservative efficacy of sweet orange peel and a conventional (brandy) preservative as control in storing plain cake within three months

\begin{tabular}{|c|c|c|c|c|c|c|c|c|c|c|c|c|}
\hline \multirow[b]{3}{*}{ CFU } & \multicolumn{12}{|l|}{ Month I } \\
\hline & \multicolumn{6}{|l|}{ 4th Day } & \multicolumn{6}{|l|}{ 5th Day } \\
\hline & $10^{1}$ & $10^{2}$ & $10^{3}$ & $10^{4}$ & $10^{5}$ & $10^{6}$ & $10^{1}$ & $10^{2}$ & $10^{3}$ & $10^{4}$ & $10^{5}$ & $10^{6}$ \\
\hline TI & $0.7 \mid \pm 0.0$ & $0.7 I \pm 0.0$ & $0.7 I \pm 0.0$ & $0.7 I \pm 0.0$ & $0.71 \pm 0.0$ & $0.7 I \pm 0.0$ & $0.71 \pm 0.0$ & $0.71 \pm 0.0$ & $0.7 I \pm 0.0$ & $0.7 I \pm 0.0$ & $0.7 I \pm 0.0$ & $0.7 I \pm 0.0$ \\
\hline $\mathrm{T} 2$ & $0.7 I \pm 0.0$ & $0.7 I \pm 0.0$ & $0.7 I \pm 0.0$ & $0.7 \mid \pm 0.0$ & $0.7 I \pm 0.0$ & $0.7 I \pm 0.0$ & $0.7 \mid \pm 0.0$ & $0.7 I \pm 0.0$ & $0.71 \pm 0.0$ & $0.7 \mid \pm 0.0$ & $0.7 I \pm 0.0$ & $0.7 \mid \pm 0.0$ \\
\hline T3 & $0.7 I \pm 0.0$ & $0.7 I \pm 0.0$ & $0.7 I \pm 0.0$ & $0.7 I \pm 0.0$ & $0.7 I \pm 0.0$ & $0.7 I \pm 0.0$ & $0.71 \pm 0.0$ & $0.7 I \pm 0.0$ & $0.71 \pm 0.0$ & $0.7 I \pm 0.0$ & $0.7 I \pm 0.0$ & $0.7 I \pm 0.0$ \\
\hline \multirow[t]{2}{*}{ C } & $1.37 \pm 0.61$ & $1.24 \pm 0.45$ & $1.24 \pm 0.45$ & $1.24 \pm 0.45$ & $1.24 \pm 0.45$ & $1.24 \pm 0.45$ & $1.91 \pm 0.0$ & $1.50 \pm 0.45$ & $1.50 \pm 0.0$ & $1.50 \pm 0.0$ & $1.50 \pm 0.0$ & $1.50 \pm 0.0$ \\
\hline & NS & NS & NS & NS & NS & NS & NS & NS & NS & NS & NS & NS \\
\hline
\end{tabular}

Table 4 showed the data.

\section{Comparative sensory attributes of orange peels preserved cakes and the control in a period of three months}

There was a significant difference in the responses to the sensory attributes of sample A and B within the three months, observed at $(\mathrm{p}<0.05)$. Table 5 showed data. 
Table continued

\begin{tabular}{|c|c|c|c|c|c|c|c|c|c|c|c|c|}
\hline \multirow[b]{3}{*}{ CFU } & \multicolumn{12}{|l|}{ Month I } \\
\hline & \multicolumn{6}{|l|}{ 4th Day } & \multicolumn{6}{|l|}{ 5th Day } \\
\hline & $10^{1}$ & $10^{2}$ & $10^{3}$ & $10^{4}$ & $10^{5}$ & $10^{6}$ & $10^{1}$ & $10^{2}$ & $10^{3}$ & $10^{4}$ & $10^{5}$ & $10^{6}$ \\
\hline TI & $0.7 I \pm 0.0 \mathrm{a}$ & $0.7 I \pm 0.0 \mathrm{a}$ & $0.7 \mathrm{I} \pm 0.0^{\mathrm{a}}$ & $0.7 \mathrm{I} \pm 0.0^{\mathrm{a}}$ & $0.7 \mathrm{I} \pm 0.0^{\mathrm{a}}$ & $0.7 I \pm 0.0$ & $0.7 I \pm 0.0^{\mathrm{a}}$ & $0.7 \mathrm{I} \pm 0.0^{\mathrm{a}}$ & $0.7 \mathrm{I} \pm 0.0^{\mathrm{a}}$ & $0.7 \mathrm{I} \pm 0.0^{\mathrm{a}}$ & $0.7 I \pm 0.0^{\mathrm{a}}$ & $0.7 \mathrm{I} \pm 0.0^{\mathrm{a}}$ \\
\hline $\mathrm{T} 2$ & $0.7 I \pm 0.0 \mathrm{a}$ & $0.7 \mathrm{I} \pm 0.0^{\mathrm{a}}$ & $0.7 \mathrm{I} \pm 0.0^{\mathrm{a}}$ & $0.7 \mathrm{I} \pm 0.0^{\mathrm{a}}$ & $0.7 \mathrm{I} \pm 0.0^{\mathrm{a}}$ & $0.7 I \pm 0.0$ & $0.7 I \pm 0.0^{\mathrm{a}}$ & $0.7 \mathrm{I} \pm 0.0^{\mathrm{a}}$ & $0.7 \mathrm{I} \pm 0.0^{\mathrm{a}}$ & $0.7 \mathrm{I} \pm 0.0^{\mathrm{a}}$ & $0.7 I \pm 0.0$ & $0.71 \pm 0.0$ \\
\hline T3 & $0.7 \mathrm{I} \pm 0.0 \mathrm{~b}$ & $0.7 I \pm 0.0^{\mathrm{a}}$ & $0.7 I \pm 0.0^{\mathrm{a}}$ & $0.7 I \pm 0.0^{\mathrm{a}}$ & $0.7 I \pm 0.0^{\mathrm{a}}$ & $0.71 \pm 0.0$ & $1.51 \pm 0.6^{b}$ & $1.51 \pm 0.6^{b}$ & $1.5 \mathrm{I} \pm 0.0^{\mathrm{b}}$ & $1.24 \pm 0.4^{\mathrm{b}}$ & $1.24 \pm 0.4^{\mathrm{ab}}$ & $1.24 \pm 0.4^{\mathrm{ab}}$ \\
\hline \multirow[t]{4}{*}{ C } & $1.91 \pm 0.0 c$ & $1.50 \pm 0.8^{c}$ & $1.50 \pm 0.0^{c}$ & $1.50 \pm 0.0^{c}$ & $1.50 \pm 0.5^{b}$ & $1.50 \pm 0.0$ & $2.4 \pm 0.2^{c}$ & $2.32 \pm 0 I^{c}$ & $2.02 \pm 0.18^{c}$ & $1.99 \pm 0.4^{c}$ & $1.74 \pm 0.4^{b}$ & $1.88 \pm 0.3^{b}$ \\
\hline & NS & NS & NS & NS & NS & NS & NS & NS & NS & NS & NS & NS \\
\hline & \multicolumn{12}{|l|}{ Month 3} \\
\hline & \multicolumn{6}{|l|}{ 4th Day } & \multicolumn{6}{|l|}{ 5th Day } \\
\hline CFU & $10^{1}$ & $10^{2}$ & $10^{3}$ & $10^{4}$ & $10^{5}$ & $10^{6}$ & $10^{1}$ & $10^{2}$ & $10^{3}$ & $10^{4}$ & $10^{5}$ & $10^{6}$ \\
\hline TI & $0.7 I \pm 0.0^{\mathrm{a}}$ & $0.7 I \pm 0.0^{\mathrm{a}}$ & $0.7 I \pm 0.0^{\mathrm{a}}$ & $0.71 \pm 0.0^{\mathrm{a}}$ & $0.7 \mathrm{I} \pm 0.0^{\mathrm{a}}$ & $0.7 \mathrm{I} \pm 0.0^{\mathrm{a}}$ & $0.7 I \pm 0.0^{\mathrm{a}}$ & $0.7 I \pm 0.0^{\mathrm{a}}$ & $0.7 \mathrm{I} \pm 0.0^{\mathrm{a}}$ & $0.7 I \pm 0.0^{\mathrm{a}}$ & $0.7 \mathrm{I} \pm 0.0^{\mathrm{a}}$ & $0.7 I \pm 0.0^{\mathrm{a}}$ \\
\hline T2 & $1.29 \pm 1.0 \mathrm{I}^{\mathrm{a}}$ & $1.29 \pm 1.0 \mathrm{I}^{\mathrm{a}}$ & $0.71 \pm 1.0^{\mathrm{a}}$ & $1.22 \pm 0.0^{\mathrm{a}}$ & $0.7 \mathrm{I} \pm 0.0^{\mathrm{a}}$ & $0.7 \mathrm{I} \pm 0.0^{\mathrm{a}}$ & $0.7 I \pm 1.70^{\mathrm{a}}$ & $0.7 I \pm 1.70^{\mathrm{a}}$ & $0.71 \pm 1.03^{a}$ & $0.7 \mathrm{I} \pm 0.0^{\mathrm{a}}$ & $0.7 \mathrm{I} \pm 0.0^{\mathrm{a}}$ & $0.7 I \pm 0.69^{a}$ \\
\hline T3 & $1.81 \pm 0.9^{b}$ & $1.90 \pm 0.0^{\mathrm{b}}$ & $1.72 \pm 0.8^{b}$ & $1.48 \pm 0.7^{b}$ & $1.23 \pm 0.4^{b}$ & $1.23 \pm 0.4^{b}$ & $1.90 \pm 0.1^{\mathrm{b}}$ & $1.82 \pm 0.9^{b}$ & $1.90 \pm 0.1^{\mathrm{b}}$ & $0.7 I \pm 0.0^{a}$ & $1.61 \pm 0.8^{b}$ & $1.48 \pm 0.7^{\mathrm{a}}$ \\
\hline C & $2.4 I \pm 0.02^{c}$ & $2.21 \pm 0.52 c$ & $2.62 \pm 0.2^{c}$ & $1.77 \pm 0.2^{c}$ & $1.63 \pm 0.2^{\mathrm{cb}}$ & $1.50 \pm 0.55^{\mathrm{cb}}$ & $2.73 \pm 0.2^{b}$ & $2.32 \pm 0.2^{\mathrm{b}}$ & $2.21 \pm 0.3^{b}$ & $2.0 \mathrm{I} \pm 0.2^{\mathrm{b}}$ & $1.88 \pm 0.4^{b}$ & $1.77 \pm 0.2^{c}$ \\
\hline
\end{tabular}

Table 5 Comparative Sensory Attribute of Sweet Orange Peels, Preserved Cake and the Control for a Period of Three Months

\begin{tabular}{llll}
\hline Sensory attribute & Month I & Month 2 & Month 3 \\
\hline Do you like the Taste of A? & $5 \pm 0.4^{\mathrm{a}}$ & $5 \pm 0.4^{\mathrm{a}}$ & $4 \pm 0.7^{\mathrm{b}}$ \\
Appearance/Texture of A? & $4 \pm 0.5^{\mathrm{a}}$ & $4 \pm 0.1^{\mathrm{a}}$ & $4 \pm 0.8^{\mathrm{a}}$ \\
Appealing Flavour of A & $5 \pm 0.0^{\mathrm{a}}$ & $5 \pm 0.4^{\mathrm{a}}$ & $5 \pm 0.4^{\mathrm{a}}$ \\
Do you like the Taste of B & $4 \pm 0.7^{\mathrm{a}}$ & $4 \pm 0.5^{\mathrm{a}}$ & $3 \pm 0.5^{\mathrm{b}}$ \\
Appearance/Texture of B & $4 \pm 0.8^{\mathrm{a}}$ & $4 \pm 0.1^{\mathrm{a}}$ & $4 \pm 0.8^{\mathrm{a}}$ \\
Appealing Flavour of B & $4 \pm 0.8^{\mathrm{a}}$ & $4 \pm 0.9^{\mathrm{a}}$ & $3 \pm 0.4^{\mathrm{b}}$
\end{tabular}

Footnote: Means tagged with different letter alphabet in the same column are significantly different at $\mathrm{p}=0.05$; Values are Mean $\pm \mathrm{SD}$

Key: I, Very Poor; 2, Poor; 3, Satisfactory; 4, Good; 5, Very Good

\section{Discussion}

The phytochemical screening of extracts (Aqueous and $\mathrm{n}$ - Hexane) and the crude powder indicates the presence of important chemical constituents found in orange peels. Okwu and Edeoga et al. ${ }^{9,10}$ stated the important bioactive ingredients to be; flavonoids, alkaloids, tannins and phenolic compounds, where all of these aforementioned constituents were more present in C.sinensis peels. Flavonoids was highly present $(+++)$ in aqueous extract than other compounds. The study conducted by Narjis et al., ${ }^{6}$ showed that petroleum ether extract of C.sinensis had a positive result of $(+)$ in all compounds except steroids which had absent. Comparing their results with the present study, the result here is far better but in comparism with Khaja et al., ${ }^{11}$ who used Aqueous extract and Ethanol extract on C.sinensis peels, the result obtained agrees with the present study.

The $\mathrm{pH}$ value obtained to be (5.6-5.6) which is slightly acidic, Tumane et al. ${ }^{12}$ Plain cake prepared using sweet orange peels as preservative against brandy; a conventional preservative revealed no significant difference in the preservative level of the three treatments with control at ( $p>0.05)$, in 24-48 hours of Month 1. In Month 2 and 3 , significant difference in effect was observed between the three treatments in for both bacteria and fungi. This implies that the control; conventional preservative brandy $(40 \%)$ preserved the cake for the first one month without any significant microorganism load whereas the C.sinensis peels preserved the cake for the three months without any significant microorganism load at ambient temperature. C.sinensis peels also preserved the cake with increase in the concentrations of the treatments where $\mathrm{T}_{1}, \mathrm{~T}_{2}, \mathrm{~T}_{3}(5 \mathrm{~g}, 3 \mathrm{~g}, 1 \mathrm{~g}$ of C.sinensis peels powder respectively) and also the storage temperature was from $27^{\circ} \mathrm{C}-21^{\circ} \mathrm{C}$ which doubled the mould free shelf life of cake ${ }^{13,14}$ therefore there is need for care during storage and distribution.

The sensory test of the sweet orange peels preserved plain cake and control, carried out among five persons and affirms that sample A (C.sinensis preserved cake) was generally preferred by the five persons over sample B (control). It was deduced that sample A and B had consistent texture from month one to month three; also it was observed that the flavor and taste of sample A was still good at the third month where sample B had it as Satisfactory. This result confirms the result obtained from the phytochemical screening of the highly presence of flavonoids $(+++)$ in the aqueous extract, also the information on the use of orange peels in baking for its distinctive flavour and taste in cake from www.bbcgoodfood.com is proven. ${ }^{15}$

\section{Conclusion}

The use of $C$. sinensis peels in this study is one way of utilizing it in a number of novel products especially in the food and pharmaceutical industries. This work has evaluated the antimicrobial activity of C. sinensis peels and it also proffered a solution to cake spoilage for at least three months. Thus, cakes when baked in a standard condition (Physically, Chemically and Microbial safe) will have less microorganisms or no microorganism growth at least for the first three 
months, when $C$. sinensis peels is used as preservatives. There is an urgent need to educate bakers on the need to use sweet orange peels as preservatives, where all the standard conditions are kept.

\section{Acknowledgment}

Author declares no acknowledgment.

\section{Conflict of interest}

Author declares no conflict of interest.

\section{References}

1. Saranraj P, Geetha M. Microbial spoilage of bakery products and its control by preservatives. International Journal of Pharmaceutical and biological Archives. 2011;3(1):38-48.

2. Bailey CP, Holy AV. Bacillus spore contamination associated with commercial bread manufacture. Food Microbiology. 1993;10(4):287-294.

3. Seiler DAL. Preservation of bakery products. Food Science and Technology Proceedings. 2000;17:35-40.

4. Manthey A, Grohmann A. Phenols in citrus peel by products: Concentrations of hydroxycinnamates and polymethoxylated flavons in citrus peel molasses. J Agric Food Chem. 2001;49(7):3268-3269.

5. Kumar AK, Narayani Subanthihi, Jayakumur. Antimicrobial activity and Phytochemical Analysis of Fruit peels - utilization of fruit waste. International Journal of Engineering Science and Technology. 2011;3(6):5414-5421.

6. Narjis HMA, Najwa SA, Shaima ES. Determination of some chemical compounds and the effect of oil extract from orange peel on some pathogens. Journal of Kerbala University. 2009;7(2):33-39.

7. Tease and Evans. Pharmacognosy. WB Sounders, London; 2000. p. 488 491.

8. History and importance of cakes. 2016.

9. Okwu DE. Evaluation of the Chemical Composition of Medical Plant belonging to Euphorbiaceace. Pak Vel S. 2001;14:160.

10. Edeoga HO, Okwu DE, Mbaebie BO. Phytochemical constituents of some Nigeria medical plants. African Journal of Biotechnology. 2005;4(7): 685688 .

11. Khaja AH, Bassel T, Binu PPK, et al. Antimicrobial Effects of Citrus sinensis Peels Extracts against periodontopathic bacteria: An invitro study. Rocz panstw zaki Hig. 2015;66(2):173-178.

12. Tumane PM, Meshram VG, Wasnik DD. Comparative Study of Antimicrobial Activity of peel Extracts of C. aurantium and C.medical against clinical isolates from wound infection. International Journal of Pharmaceutical and Biological Science. 2014;5(1):382-387.

13. Chamberlain N. Mould growth on cake. Biscuit Maker and Plant Baker. 1993;14:961-964.

14. Albellana, M., Sanchis, V and Ramos ML. Effect of water activity and temperature on growth of three Penicillum species and Aspergillus flavus on a sponge cake analogue. International Journal of Food Microbiology. 2001;71(2-3):151-157.

15. The use of orange peels in cake baking. 2016. 